\title{
The Effects of Learning Models of Discovery Learning and Learning Interest on Social Science Learning Outcomes in Grade VII of Junior High School of Al-Azhar Medan
}

\author{
Andi Irawan ${ }^{1}$, Dede Ruslan², Aman Simare mare ${ }^{2}$ \\ ${ }^{1}$ Master Student in State University of Medan (Unimed), Medan, Indonesia \\ ${ }^{2}$ Lecturer in State University of Medan (Unimed), Medan, Indonesia \\ andialazhar87@gmail.com
}

\begin{abstract}
This study deals with the effects of learning models of discovery learning and learning interest on social science learning outcomes in grade VII of Junior High School of Al-Azhar Medan. This study was conducted in the Even Semester of the Learning Year 2018/2019, which began in April to May 2019 with stages: observation, determining the experimental class and the control class, preparation of research instruments, instrument testing, pre-test administration, giving questionnaires of interest, treatment, giving post-tests, processing data, analyzing data, drawing conclusions. The conclusion of this study were there is a significant effects of learning models of discovery learning on social science learning outcomes in grade VII of Junior High School of Al-Azhar Medan $\left(F_{\text {count }}=306,594 ; P=0,000\right)$. There is a significant effects of learning interest in social science learning outcomes in grade VII of Junior High School of Al-Azhar Medan $\left(F_{\text {count }} 69,071 ; P=0,000\right)$. There is a significant interaction between Discovery Learning models and learning interest in social science learning outcomes in grade VII of Junior High School of Al-Azhar Medan $\left(F_{\text {count }}=5,288\right.$; $P=$ 0,012 ).
\end{abstract}

Keywords : learning models; discovery learning; learning interest.

\section{Introduction}

Learning interest that exists in students can play an important role and influence learning outcomes when learning models designed by teachers can make students free to express and explore their abilities optimally. Student achievement in a subject is dependent on interest because interest is a factor that determines the achievement of learning goals (Roida, 2008: 124). To overcome the above problems, the teacher must be able to try to improve and develop the quality of the social science learning process in accordance with the cognitive needs and intellectual skills of students. So that the concept of the subject matter "The Development of the Period of Islam in Indonesia" which is abstract in nature can be understood by all students easily and more meaningfully. One model in social science learning that is oriented towards this is to apply the Discovery Learning model.

Learning outcomes derived from giving problems to students will provide stronger retention power because concepts are built on their own experience, this is in line with what was expressed by Paulo Freire in his book Pedagogy of the opressed saying that educators must raise problems to students to solve, not just giving the right answer to remember. Learning models that involve the activeness of students by giving problems to be solved will give far better and more lasting results than giving verbal information (Meier, 2002).

The Discovery Learning model is used to find several concepts and principles in the material "Development of the Period of Islam in Indonesia". By using this model, students are required to carry out various activities to gather information, compare, categorize, analyze, integrate, reorganize material materials and make their own conclusions regarding the process of entering and developing Islamic religion in Indonesia. 


\section{Review of Literatures}

\subsection{Nature of Learning}

According to Pidarta (2009: 206) learning is a behavior change that is relatively permanent as a result of experience (not the results of development, the influence of drugs, or accidents) and can implement it on other knowledge and be able to communicate it to others. Someone is considered to have learned something if he can show changes in his behavior. According to this theory, in learning what is important is input in the form of stimulus and output in the form of response. Stimulus is whatever is given by the teacher to the learner, while the response is in the form of a reaction or learner's response to the stimulus given by the teacher, the process that occurs between stimulus and response is not important to note because it cannot be observed and cannot be measured. What can be observed is stimulus and response, therefore what is given by the teacher (stimulus) and what is received by the learner (response) must be observable and measured. This theory prioritizes measurement, because measurement is an important thing to see whether or not changes in behavior occur.

Skinner explained that reward or reinforcement has a very important role in the learning process. In his theory Skinner states that reinforcement consists of positive and negative reinforcement. Strengthening can be considered a positive stimulus, if the reinforcement is in line with the increasing behavior of children in doing repetition of that behavior. In this case the reinforcement given to children will strengthen children's actions, so that children do it more often. To change a child's behavior from negative to positive, the teacher needs to know the psychology that can be used to estimate it and control the child's behavior. Teachers in the classroom have the task of directing children in learning activities. Because at the time of learning, control is in the teacher who has the authority to give instructions or prohibitions to his students. Skinner added that if the student's response is good then positive reinforcement must be given so that the response is better.

\subsection{The Nature of Social Sciences (IPS)}

IPS is one of the subjects given starting from elementary / MI / SDLB to high school / MA / SMK. Social science examines a set of events, facts, concepts, and generalizations relating to social issues (E. Mulyasa, 2007: 125). In addition to this understanding, IPS has a broader meaning as stated by the National Council for Social science / NCSS (Sapriya, 2009: 10) that Social science is the integrated study of the social sciences and humanities to promote civic competence. Within the school program, social science provides coordinated, systemic study drawing, upon such disciplines as anthropology, archaeology, economics, geography, history, law, philosophy, political science, psychology, religion, and sociology, as well as appropriate content from the humanities, mathematics, and natural sciences.

From the above understanding, it can be said that social science is a social study that combines social science and humanities to improve citizenship competencies. With the school program, IPS is developed with a systematic mix based on anthropology, archeology, economics, geography, history, law, philosophy, political science, psychology, religion, and sociology, as well as material needed from the humanities, mathematics, and natural sciences. The definition of IPS according to Ischak is not much different from the statement from NCSS that social science is a field of study that studies, examines, analyzes symptoms and social problems in society by reviewing various aspects of life or one combination (Ischak SU, 1997: $1-30)$. 


\subsection{The Nature of Learning Models}

Learning is a combination of teaching activities carried out by teachers and learning activities carried out by students. In these learning activities, there is interaction between students and students, interactions between teachers and students, and interactions between students and learning resources. It is expected that with these interactions, students can actively build knowledge, learning takes place interactively, inspiring, fun, challenging, and can motivate students to achieve the expected competencies.

The word learning is a translation of instruction, which is widely used in the world of education in the United States, this term is much influenced by the flow of cognitive-wholistic psychology, which applies students as a source of activity. In addition, this term is also influenced by technological developments which are assumed to facilitate students to learn something through various kinds of media such as printed materials, television programs, images, audio, and so on. Thus, all of that encourages a change in the teacher's role in managing the learning process, from the teacher as a source of learning to being a teacher as a facilitator in learning (Fathurrohman, 2015: 15).

\subsection{Discovery Learning Models}

Discovery Learning has the meaning of discovery. In applying the model this emphasizes the importance of understanding the structure or important ideas of a scientific discipline, through the active involvement of student's in learning process. Budiningsih (2005: 43) argues that the Discovery Learning strategy is to understand concepts, meanings, and relationships, through an intuitive process to finally come to a conclusion. While Robert B. Sund in Malik (2001: 219) argues that Discovery occurs when individuals are involved, especially in the use of mental processes to find several concepts and principles. Discovery is done through observation, classification, measurement, prediction, determination. The process is cognitive process, while discovery itself is the mental process of assimilating conception and principles in the mind.

In applying the Discovery Learning model not only requires students to be more active in learning, in this learning model also requires students to develop abilities that exist in him, such as the ability of observation, analysis, prediction and determination. Bell (1978) argues that learning discovery is learning that occurs as a result of learners manipulating structures and transforming information so that they find new information. In learning discovery, students can make estimates, form a hypothesis and find the truth by using inductive processes or deducative processes, making observations and making extrapolations. Support the opinion above Fred JJM Janssen (2014: 2, "How to use discovery learning practical for student teachers".) The common aspect of different practices is that teaching starts by posing a challenging problem, and that students themselves contribute to the knowledge development needed to solve the problem.

\section{Research Methods}

This research was conducted at Junior High School of Al-Azhar Medan which located in Pintu Air IV Street No. 214 Kwala Bekala Village, Medan Johor Subdistrict. The reason for conducting research in this school is that there is still a direct learning model that focuses on the teacher as the only source of knowledge. 
This research was conducted for 2 months in the Even Semester of the Learning Year 2018/2019, which began in April to May 2019 with stages: observation, determining the experimental class and the control class, preparation of research instruments, instrument trials, pre-test, giving questionnaires of interest, treatment, giving post-tests, processing data, analyzing data, drawing conclusions.

\section{Discussion}

\subsection{Research Result}

4.1.1. Student Pre-Test Results

The results of the Student Pre-Test are presented in Table 1.

Table 1. Student Pre-Test Results

\begin{tabular}{cccccc}
\hline No. & $\begin{array}{c}\text { Learning } \\
\text { Model }\end{array}$ & $\begin{array}{c}\text { Average } \\
\text { Pre-Test }\end{array}$ & $\begin{array}{c}\text { Minimum } \\
\text { Score }\end{array}$ & $\begin{array}{c}\text { Maximum } \\
\text { Score }\end{array}$ & $\begin{array}{c}\text { Standard } \\
\text { Deviation }\end{array}$ \\
\hline 1. & $\begin{array}{l}\text { Discovery } \\
\text { Learning }\end{array}$ & 65,41 & 40,00 & 90,00 & 12,40 \\
2. & Expository & 64,22 & 43,33 & 76,67 & 9,58 \\
\hline
\end{tabular}

\subsubsection{Student Learning Interest Score}

Student Learning Interest Score is presented in Table 2.

Table 2. Student Learning Interest Score

\begin{tabular}{cccccc}
\hline No. & $\begin{array}{l}\text { Learning } \\
\text { Model }\end{array}$ & $\begin{array}{c}\text { Average } \\
\text { Learning Interest }\end{array}$ & $\begin{array}{c}\text { Minimum } \\
\text { Score }\end{array}$ & $\begin{array}{c}\text { Maximum } \\
\text { Score }\end{array}$ & $\begin{array}{c}\text { Standard } \\
\text { Deviation }\end{array}$ \\
\hline 1. & $\begin{array}{l}\text { Discovery } \\
\text { Learning }\end{array}$ & 105,96 & 76 & 133 & 16,99 \\
2. & Expository & 97,03 & 62 & 123 & 16,18 \\
\hline
\end{tabular}

\subsubsection{Student learning outcomes}

Student Learning Outcomes are presented in Table 3.

Table 3. Student Learning Outcomes

\begin{tabular}{llcccc}
\hline No. & Learning Model & $\begin{array}{c}\text { Average Student } \\
\text { Learning Outcomes }\end{array}$ & $\begin{array}{c}\text { Minimum } \\
\text { Score }\end{array}$ & $\begin{array}{c}\text { Maximum } \\
\text { Score }\end{array}$ & $\begin{array}{c}\text { Standard } \\
\text { Deviation }\end{array}$ \\
\hline 1. & $\begin{array}{l}\text { Discovery } \\
\text { Learning }\end{array}$ & 84,68 & 73,33 & 96,67 & 6,27 \\
2. & Expository & 74,66 & 56,67 & 90,00 & 6,70 \\
\hline
\end{tabular}

4.1.4. Recapitulation of Student Learning Outcomes that have High and Low Learning Interests

Recapitulation of Learning Outcomes Students who have a High and Low Interest in Learning are presented in Table 4. 
Table 4. Recapitulation of Student Learning Outcomes that have High and Low Learning Interests

\begin{tabular}{|c|c|c|c|}
\hline No. & Learning & $\begin{array}{c}\text { Average Learning } \\
\text { Outcomes }\end{array}$ & $\begin{array}{c}\text { Average Interest in } \\
\text { Learning }\end{array}$ \\
\hline 1. & $\begin{array}{l}\text { Learning outcomes of students who } \\
\text { have high learning interest are taught } \\
\text { using learning models of Discovery } \\
\text { Learning }\left(\mathrm{A}_{1} \mathrm{~B}_{1}\right)\end{array}$ & 90,22 & 122,27 \\
\hline 2. & $\begin{array}{l}\text { Learning outcomes of students who } \\
\text { have low learning interest are taught } \\
\text { using learning models of Discovery } \\
\text { Learning }\left(\mathrm{A}_{1} \mathrm{~B}_{2}\right)\end{array}$ & 79,80 & 91,59 \\
\hline 3. & $\begin{array}{l}\text { Learning outcomes of students who } \\
\text { have high learning interest are taught } \\
\text { using learning models of Expository } \\
\left(\mathrm{A}_{2} \mathrm{~B}_{1}\right)\end{array}$ & 79,77 & 110,33 \\
\hline 4. & $\begin{array}{l}\text { Learning outcomes of students who } \\
\text { have low learning interest are taught } \\
\text { using learning models of } \\
\text { Expository }\left(\mathrm{A}_{2} \mathrm{~B}_{2}\right)\end{array}$ & 69,55 & 83,73 \\
\hline
\end{tabular}

\subsubsection{Data Normality Test Results}

Based on the results of the normality test, the overall data is normally distributed with a significant value above 0.05 . Normality Test Results Data are presented in Table 5.

Table 5. Data Normality Test Results

\begin{tabular}{|c|c|c|c|c|}
\hline \multirow[t]{2}{*}{ No. } & \multirow[t]{2}{*}{ Data } & \multicolumn{2}{|c|}{$\begin{array}{c}\text { Normality test } \\
\text { Kolmogorov-Smirnov }\end{array}$} & \multirow[t]{2}{*}{ Information } \\
\hline & & Statistics & Significant & \\
\hline 1. & $\begin{array}{l}\text { Classroom Student } \\
\text { Learning Outcomes } \\
\text { of Discovery } \\
\text { Learning }\end{array}$ & 0,117 & 0,200 & Normal Distribution \\
\hline 2. & $\begin{array}{l}\text { Classroom Student } \\
\text { Learning Outcomes } \\
\text { of Expository }\end{array}$ & 0,121 & 0,200 & Normal Distribution \\
\hline 3. & $\begin{array}{l}\text { Interest in Class } \\
\text { Student Learning of } \\
\text { Discovery Learning }\end{array}$ & 0,153 & 0,054 & Normal Distribution \\
\hline 4. & $\begin{array}{l}\text { Interest in Class } \\
\text { Student Learning of } \\
\text { Expository }\end{array}$ & 0,077 & 0,200 & Normal Distribution \\
\hline
\end{tabular}

\subsubsection{Data Homogeneity Test Results}

Based on the results of the homogeneity test data, the overall data is homogeneous with a significant value above 0.05. Homogeneity Test Results Data are presented in Table 6. 
Table 6. Data Homogeneity Test Results

\begin{tabular}{|c|c|c|c|c|c|}
\hline \multirow[t]{2}{*}{ No. } & \multirow{2}{*}{\multicolumn{2}{|c|}{ Data }} & \multicolumn{2}{|c|}{$\begin{array}{c}\text { Homogeneity Test } \\
\text { Levene's }\end{array}$} & \multirow[t]{2}{*}{ Information } \\
\hline & & & Statistics & Significant & \\
\hline 1. & $\begin{array}{l}\text { Student } \\
\text { outcomes }\end{array}$ & learning & 0,006 & 0,937 & Homogeneous \\
\hline 2. & $\begin{array}{l}\text { Interest in } \\
\text { Learning }\end{array}$ & Student & 0,966 & 0,330 & Homogeneous \\
\hline
\end{tabular}

\subsection{Hypothesis Testing}

\subsubsection{The Effect of Discovery Learning Model on Student Learning Outcomes}

Based on the results of the Analysis of Variance (Anava) obtained a significant value for Learning Model $=0,000$. Then the significant value for Learning is smaller than the significance level $=0.05(0,000<0,05)$. So that the alternative hypothesis $\left(h_{a}\right)$ is accepted which states that there is a significant effect of the Discovery Learning model on social science learning outcomes in grade VII of Junior High School of Al-Azhar Medan. $\left(F_{\text {count }}=306,594\right.$; $\mathrm{P}=0,000)$.

Based on the results of the $t$ test, it was found that there was a significant comparison of student learning outcomes taught using the Discovery Learning model with the Expository learning model ( $\mathrm{t}$-count $=6.083 ; \mathrm{P}=0,000)$. Where student learning outcomes are taught with Discovery Learning models $(84.68 \pm 6.27)( \pm$ SD) higher than those taught by using Expository learning models $(74.66 \pm 6.70)$. Comparison of Student Learning Outcomes Taught Using Discovery Learning Models with Expository Learning Models (t-count $=6.083 ; \mathrm{P}=0,000)$ are presented in Figure 1.

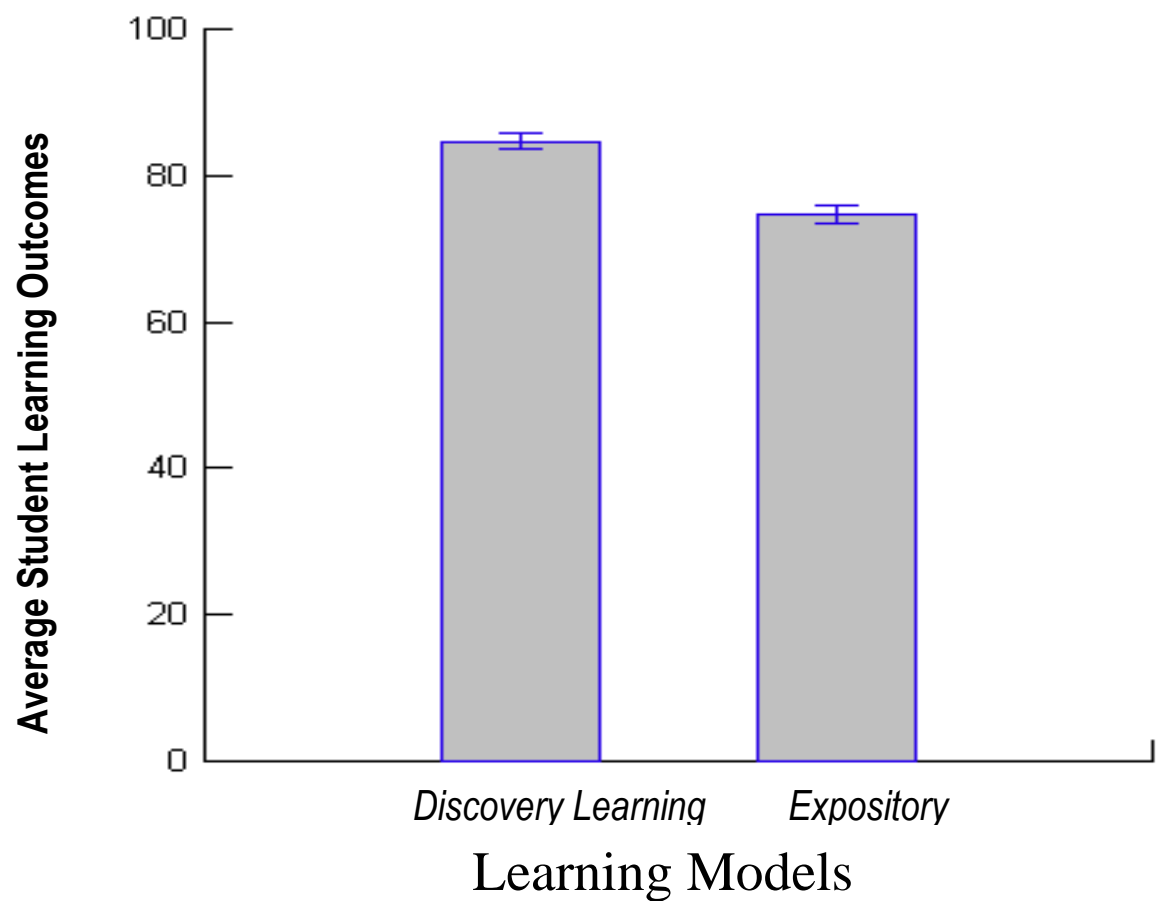

Figure 1. Comparison of Student Learning Outcomes Taught Using Discovery Learning Models with Expository Learning Models $(\mathrm{t}$-count $=6.083 ; \mathrm{P}=0,000)$ 


\subsubsection{Effects of Interest in Learning on Student Learning Outcomes}

Based on the results of the Analysis of Variance (Anava) obtained a significant value for Student Learning Interest $=0,000$. Then the significant value for Student Learning Interest is smaller than the significance level $=0.05(0,000<0,05)$. So that the alternative hypothesis $\left(h_{a}\right)$ is accepted which states that there is a significant effect of interest in learning on social science learning outcomes in class VII of Junior High School of Al-Azhar Medan $\left(\mathrm{F}_{\text {count }}=69,071 ; \mathrm{P}=\right.$ 0,000).

Where the average difference (1) learning outcomes of students who have a high interest in learning taught by using the learning model Discovery Learning $\left(\mathrm{A}_{1} \mathrm{~B}_{1}\right)$ obtained $90.22 \pm$ 3.66; (2) learning outcomes of students who have low learning interest taught by using the Discovery Learning $\left(\mathrm{A}_{1} \mathrm{~B}_{2}\right)$ learning model obtained $79.80 \pm 3.21$; (3) learning outcomes of students who have high learning interest who are taught using the Expository learning model $\left(\mathrm{A}_{2} \mathrm{~B}_{1}\right)$ obtained $79.77 \pm 4.07$; and (4) learning outcomes of students who have low learning interest who are taught using the Expository learning model $\left(\mathrm{A}_{2} \mathrm{~B}_{2}\right)$ obtained $69.55 \pm 4.51$.

\subsubsection{Interaction of Discovery Learning Model and Learning Interest towards Student Learning Outcomes}

Based on the results of the Analysis of Variance (Anava) obtained a significant value for the interaction between the Learning Model and the Interest of Student Learning towards Student Learning Outcomes $=0.012$. Then the significant value for the interaction between the Learning Model and the Interest in Student Learning towards Student Learning Outcomes is smaller than the significance level $=0.05(0.012<0.05)$. So that the alternative hypothesis (ha) is accepted which states that there is a significant interaction between the Discovery Learning model and interest in learning towards social science learning outcomes in grade VII of Junior High School of Al-Azhar Medan ( F count = 5.288; $\mathrm{P}=0.012)$.

\subsubsection{Advanced Test (Post Hoc)}

Because there is a significant interaction between the Discovery Learning model and student learning interest in social science learning outcomes in the seventh grade of Junior High School of Al-Azhar in Medan, Scheffe's further tests were carried out on the treatment group. Based on the results of the Advanced Test (Post Hoc) on the Scheffe Test it was found that:

1. There are significant differences in learning outcomes of students who have a high learning interest taught by using the learning model Discovery Learning $\left(\mathrm{A}_{1} \mathrm{~B}_{1}\right)$ obtained $90.22 \pm 3.66$ on learning outcomes of students who have low learning interest who are taught using the Discovery Learning model $\left(\mathrm{A}_{1} \mathrm{~B}_{2}\right)$ obtained $79.80 \pm 3.21(\mathrm{P}=0,000)$.

2. There are significant differences in learning outcomes of students who have high learning interest taught by using the learning model Discovery Learning $\left(\mathrm{A}_{1} \mathrm{~B}_{1}\right)$ obtained $90.22 \pm$ 3.66 on learning outcomes of students who have high learning interest who are taught using the Expository learning model $\left(\mathrm{A}_{2} \mathrm{~B}_{1}\right)$ obtained $79.77 \pm 4.07(\mathrm{P}=0,000)$.

3. There are significant differences in learning outcomes of students who have high learning interest taught by using the learning model Discovery Learning $\left(\mathrm{A}_{1} \mathrm{~B}_{1}\right)$ obtained $90.22 \pm$ 3.66 on learning outcomes of students who have low learning interest who are taught using the Expository learning model $\left(\mathrm{A}_{2} \mathrm{~B}_{2}\right)$ obtained $69.55 \pm 4.51(\mathrm{P}=0,000)$.

4. There is no significant difference in learning outcomes of students who have low learning interest taught by using the learning model Discovery Learning $\left(\mathrm{A}_{1} \mathrm{~B}_{2}\right)$ obtained $79.80 \pm$ 3.21 on learning outcomes of students who have high learning interest who are taught using the Expository learning model $\left(\mathrm{A}_{2} \mathrm{~B}_{1}\right)$ obtained $79.77 \pm 4.07(\mathrm{P}=1,000)$. 
5. There are significant differences in learning outcomes of students who have low learning interest taught by using the learning model Discovery Learning $\left(\mathrm{A}_{1} \mathrm{~B}_{2}\right)$ obtained $79.80 \pm$ 3.21 on learning outcomes of students who have low learning interest who are taught using the Expository learning model $\left(\mathrm{A}_{2} \mathrm{~B}_{2}\right)$ obtained $69.55 \pm 4.51(\mathrm{P}=0,000)$.

6. There are significant differences in the learning outcomes of students who have high learning interest who are taught using the Expository learning model $\left(\mathrm{A}_{2} \mathrm{~B}_{1}\right)$ obtained $79.77 \pm 4.07$ on learning outcomes of students who have low learning interest who are taught using the Expository learning model $\left(\mathrm{A}_{2} \mathrm{~B}_{2}\right)$ obtained $69.55 \pm 4.51(\mathrm{P}=0,000)$.

Comparison of Learning Outcomes of Students with High and Low Learning Interests Taught Using Discovery Learning Models and Expository Learning Models are presented in Figure 2.

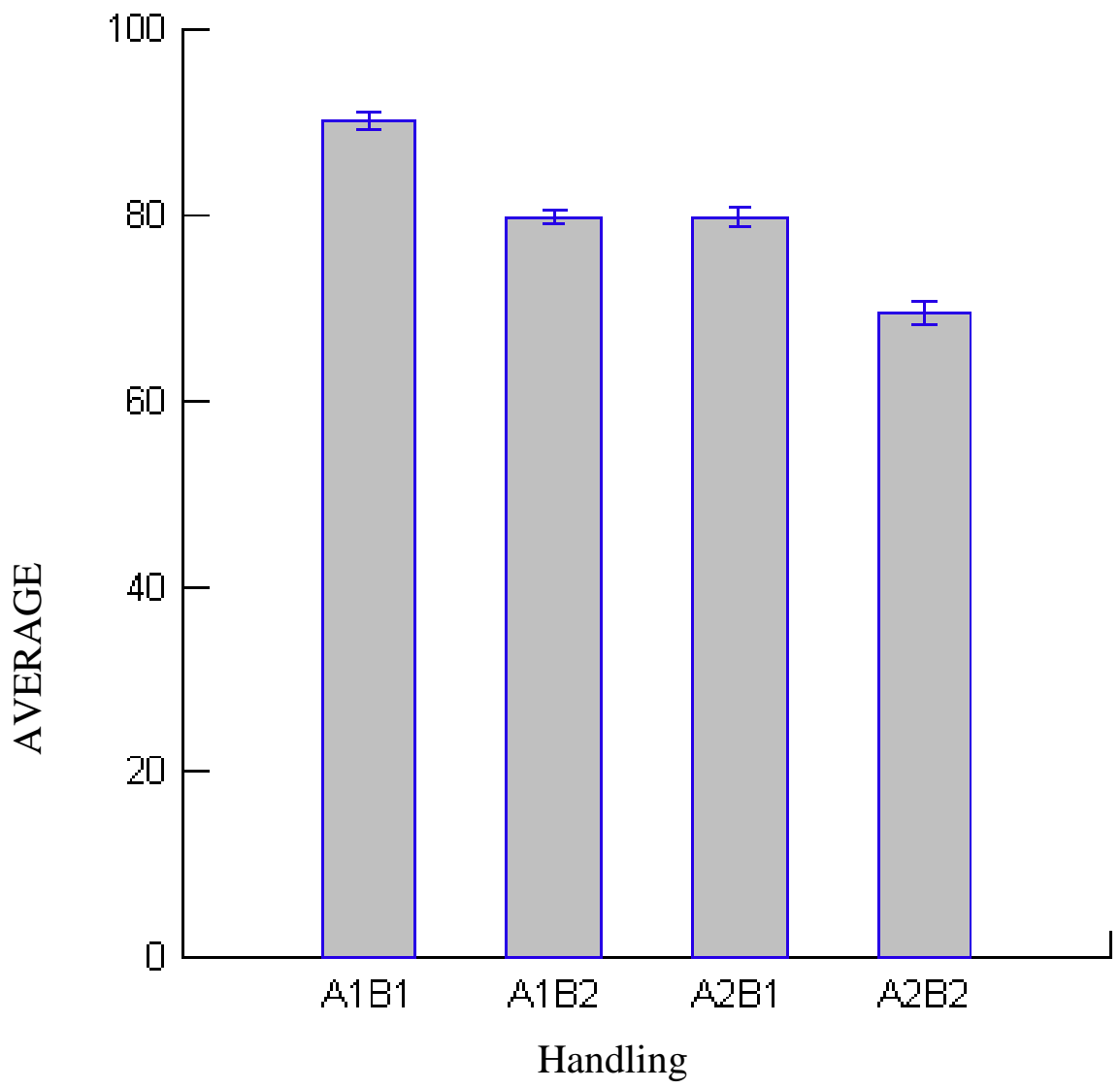

Figure 2. Comparison of Learning Outcomes of Students with High and Low Learning Interests Taught Using Discovery L earning Models and Expository Learning Models

Information:

$\mathrm{A}_{1} \mathrm{~B}_{1}$ : Average Social science learning outcomes taught with Discovery learning models Learning for students with a high interest in learning.

$\mathrm{A}_{1} \mathrm{~B}_{2}$ : Average Social science learning outcomes taught with Discovery learning models Learning for students with low learning interest. 
$\mathrm{A}_{2} \mathrm{~B}_{1} \quad$ : Average Social science learning outcomes taught with Expository learning models to students with a high interest in learning.

$\mathrm{A}_{2} \mathrm{~B}_{2} \quad$ : Average Social science learning outcomes taught with Expository learning models in students with low interest in learning.

Learning outcomes of students who have a high interest in learning taught by using the learning model of Discovery Learning $\left(\mathrm{A}_{1} \mathrm{~B}_{1}\right)$ obtained $90.22 \pm 3.66$ have the highest score and differ significantly compared to the others. Learning outcomes of students who have low learning interest taught by using the learning model Discovery Learning $\left(\mathrm{A}_{1} \mathrm{~B}_{2}\right)$ obtained 79.80 \pm 3.21 not significantly different than the learning outcomes of students who have high learning interest who are taught using the Expository learning model $\left(\mathrm{A}_{2} \mathrm{~B}_{1}\right)$ obtained $79.77 \pm 4.07$, but differed significantly from the learning outcomes of students who had low learning interest who were taught using the Expository learning model $\left(\mathrm{A}_{2} \mathrm{~B}_{2}\right)$ obtained $69.55 \pm 4.51$ and learning outcomes of students who had high learning interest who were taught using the learning model Discovery Learning $\left(\mathrm{A}_{1} \mathrm{~B}_{1}\right)$ obtained $90.22 \pm$ 3.66. Learning outcomes of students who have low learning interest who are taught using the Expository learning model $\left(\mathrm{A}_{2} \mathrm{~B}_{2}\right)$ obtained $69.55 \pm 4.51$ having the lowest score and significantly different compared to the others.

\subsection{Discussion}

4.3.1. The effect of Discovery Learning Model on Social science Learning Outcomes in grade VII of Junior High School of Al-Azhar Medan.

In the results of this study it was found that there was a significant effect of the Discovery Learning model on social science learning outcomes in grade VII of Junior High School of AlAzhar Medan $(\mathrm{F}$ count $=306,594 ; \mathrm{P}=0,000)$. Where student learning outcomes are taught with Discovery Learning models $(84.68 \pm 6.27)( \pm \mathrm{SD})$ higher than those taught by using Expository learning models $(74.66 \pm 6.70)$. This is because the Discovery Learning model is a learning process that develops students' thinking skills in terms of observing, analyzing, predicting and drawing conclusions. As Bell (1978) states that the Discovery Learning model is learning discovery where in the learning process occurs as a result of learners manipulating the structure and transforming knowledge information to find new information. In learning discovery, students can make estimates, form a hypothesis and find the truth by using inductive processes or deducative processes, making observations and making extrapolations.

Therefore, the Discovery Learning model directs students to find concepts clearly, deeply, while developing the critical and creative thinking that they have. Students are guided to raise problems or puzzles with questions that can motivate students as well as be able to understand the concepts of social science subject matter more deeply and clearly. Through the problems of social science learning materials students can get used to improve their memory by developing critical and creative thinking, and can improve student learning outcomes for the better.

Thus Discovery Learning is an active learning by instilling attitudes in research. So that students are able to develop themselves according to their abilities in implementing learning models so that students become easily understood in learning materials well, not just limited to the theory, but also its application in society. In the hope that students are able to solve and find solutions to solve each learning problem in its application in social life. 
4.3.2. The effects of learning models of discovery learning and learning interest on social science learning outcomes in grade VII of Junior High School of Al-Azhar Medan.

In the results of this study it was found that there was a significant effects of learning models of discovery learning and learning interest on social science learning outcomes in grade VII of Junior High School of Al-Azhar Medan. $\left(F_{\text {count }}=69,071 ; P=0,000\right)$. Where the average difference (1) learning outcomes of students who have a high interest in learning taught by using the learning model Discovery Learning $\left(\mathrm{A}_{1} \mathrm{~B}_{1}\right)$ obtained $90.22 \pm 3.66$; (2) learning outcomes of students who have low learning interest taught by using the Discovery Learning $\left(\mathrm{A}_{1} \mathrm{~B}_{2}\right)$ learning model obtained $79.80 \pm 3.21$; (3) learning outcomes of students who have high learning interest who are taught using the Expository learning model $\left(\mathrm{A}_{2} \mathrm{~B}_{1}\right)$ obtained $79.77 \pm$ 4.07; and (4) learning outcomes of students who have low learning interest who are taught using the Expository learning model $\left(\mathrm{A}_{2} \mathrm{~B}_{2}\right)$ obtained $69.55 \pm 4.51$.

This is because interest is a feeling of preference and interest in students in social science subjects. Therefore, students show their interest in learning when they take part in the learning process of social science material which is implemented through active participation of students in the learning process in the classroom. Where students who have an interest in learning tend to give greater attention to social science subject matter. As Hilgard (in Slameto, 2010: 180) states that interest is a fixed tendency to pay attention and remember some activities. Activities that are of interest to a person, continuous attention that is accompanied by pleasure. So it is different from attention, because attention is temporary (not for a long time) and not necessarily followed by feeling happy, while interest is always followed by feelings of pleasure and from there satisfaction is obtained.

Because intensive concentration on social science material gives students to study harder, and finally achieve the desired achievement. This was stated by According to Shah (2010: 133) interest (interest) means a tendency and high enthusiasm or a great desire for something, interest as understood and used by people so far can affect the quality of achievement of student learning outcomes in the fields of study certain. For example, a student who has a great interest in mathematics will focus more on other students.

\subsubsection{Interaction between Discovery Learning Model and Learning Interest on social science} learning outcomes in grade VII of Junior High School of Al-Azhar Medan.

Based on the results of this study it was found that there was a significant interaction between the Discovery Learning model and interest in learning towards social science learning outcomes in grade VII of Junior High School of Al-Azhar Medan $\left(\mathrm{F}_{\text {count }}=5.288 ; \mathrm{P}=0.012\right)$. This is due to the Discovery Learning Model applying understanding of structures or important ideas to a discipline, through active involvement of students in the learning process in social science subjects in the classroom. As Robert B. Sund in Malik (2001: 219) states that Discovery learning occurs when individuals are involved, especially in the use of mental processes to find several concepts and principles. Discovery learning is done through observation, classification, measurement, prediction, determination. The process is cognitive process, while discovery itself is the mental process of assimilating conception and principles in the mind.

\section{Conclusion}

There is a significant effect of the Discovery Learning model on social science learning outcomes in grade VII of Junior High School of Al-Azhar Medan $\left(\mathrm{F}_{\text {count }}=306,594 ; \mathrm{P}=0,000\right)$. 
There is a significant effect of learning interest on social science learning outcomes in grade VII of Junior High School of Al-Azhar Medan $\left(\mathrm{F}_{\text {Count }}=69,071 ; \mathrm{P}=0,000\right)$. There is a significant interaction between Discovery Learning models and learning interest on social science learning outcomes in grade VII of Junior High School of Al-Azhar Medan $\left(\mathrm{F}_{\text {count }}=\right.$ $5,288 ; \mathrm{P}=0,012)$.

\section{References}

Arikunto, S., (2009). Prosedur Penelitian Suatu Pendekatan Praktik. Revised Edition 6. Jakarta : Rineka Cipta.

Ambarita, Biner and Paningkat, S. (2013). Manajemen Pendidikan dan Komunikasi. Bandung : Alfabeta.

Balım, A., G. (2009). The Effects of Discovery Learning on Students' Success and Inquiry Learning Skills. Egitim Arastirmalari-Eurasian Journal of Educational Research, 35, 120.

Balitbang Puskur. (2001). Kurikulum Berbasis Kompetensi Mata Pelajaran Kewarganegaaraan SMA/SMK. Jakarta: Depdiknas.

Bell, F.H. (1978). Teaching and Learning Mathematics in Scondary School. New York: Wm C Brown Company Publiser.

Budiningsih, Asri. (2005). Belajar dan Pembelajaran. Jakarta: Rineka Cipta.

Dahar, R.W. (2006). Teori-teori Belajar dan Pembelajaran. Jakarta : Erlangga.

Depdiknas. (2006). Kurikulum 2006 Standar Kompetensi Mata Pelajaran. Depdiknas: Jakarta.

Depdikbud. (2001). Kamus Besar Bahasa Indonesia. Jakarta : Balai Pustaka.

Dimyati and Mudjiono. (2009). Belajar dan Pembelajaran. Jakarta : Rineka Cipta.

Djamarah, Syaiful B. (2011). Psikologi Belajar. Jakarta : Rineka Cipta.

Fakih Samlawi, Bunyamin Maftuh. (1999). Konsep Dasar IPS. Departemen Pendidikan dan Kebudayaan. Jakarta.

Fathurrohman, Muhammad. (2015). Model-model Pembelajaran Inovatif. Yogyakarta: Arruzz Media.

Gagne, R.M. (1977). The Conditions of Learning. New York: Holt Rinehart and Winston.

Ginting, Inriyatni, (2014). "Minat Siswa Kelas X dan XI IPS Terhadap Mata Pelajaran Geografi pada Semester Genap TP. 2013/2014”. Skripsi. Medan: Jurusan Pendidikan Geografi FIS-Unimed.

Hamalik, Oemar. (2009). Kurikulum dan Pembelajaran. Jakarta: Bumi Aksara.

Harjanto. (2011). Perencanaan Pengajaran. Jakarta : Rineka Cipta.

Hosnan. (2014). Pendekatan Saintifik dan Kontekstual dalam Pembelajaran Abad 21. Bogor: Ghalia Indonesia.

Keys, C. W. \& Bryan, L. A. (2001). Co-constructing inquiry-based science with teachers: Essential research for lasting reform. Journal of Research in Science Teaching : Vol : 38, 631-645.

Lie, Anita. (2007). Cooperative Learning. Jakarta : Grasindo.

Malik. (2001). Metode Belajar dan Kesulitan-kesulitan Belajar. Bandung: Tarsito.

Markaban, (2006). Model Pembelajaran Matematika dengan Pendekatan Penemuan Terbimbing. Yogyakarta : Departemen Pendidikan Nasional PPPG Matematika.

Meier, Dave. (2002). The Accelerated Learning Handbook Panduan Kreatif dan Efektif Merancang Program Pendidikan dan Pelatihan. Bandung : Kaifa. 
Roida, (2008). Pengaruh Minat dan Kebiasaan Belajar Siswa terhadap Prestasi Belajar Matematika. Jurnal Formatif. Vol. 2 (2), pp. 122-131.

Rusman, (2011). Model-model Pembelajaran: Mengembangkan Profesionalisme Guru, Jakarta: Rajagrafindo Persada.

Rusman. (2012). Belajar dan Pembelajaran Berbasis Komputer Mengembangkan

Profesionalisme Guru Abad 21. Bandung: Alfabeta.

Sablonnie, Taylor and Sadykova (2009). "Challenges of applying a student-centered approach to learning in the context of education in Kyrgyzstan". Journal of Educational Development. G Model EDEV-1142; No of Pages 7. Doi:10.1016/j.ijedudev.2009.01.001 (Accessed on 1 January 2019).

Sagala, Syaiful. (2009). Konsep dan Makna Pembelajaran. Bandung : Alfabeta.

Sapriya, (2009). Pendidikan IPS Konsep dan Pembelajaran. Bandung : Remaja Rosdakarya.

Suparman, Atwi. (2014). Desain Instruksional Modern : Panduan Para Pengajar dan Inovator Pendidikan. Jakarta : Erlangga.

Suprijono. (2010). Cooperative Learning. Yogyakarta. Pustaka Media.

Syah. (2004). Psikologi Pendidikan dengan Pendekatan Baru. Bandung: Remaja Rosdakarya. Syah, Muhabibbin. (2010). Psikologi Pendidikan dengan Pendekatan Baru. Bandung : Remaja Rosdakarya.

Tatar, N. \& Kuru, M. (2006). The Effect Of Inquiry-Based Learning Approach In Science Education On Academic Achievement, Hacettepe University. Journal of Education, 31, 147-158.

Trianto. (2010). Model Pembelajaran Terpadu Konsep, Strategi, dan Implementasinya dalam Kurikulum Tingkat Satuan Pendidikan (KTSP) Edisi2. Edisi Kedua.Jakarta: Bumi aksara.

Unal, G. \& Ergin, Ö. (2006). The Impact Of Science Learning Through Invisibility On Students' Academic Achievement, Learning Attitudes, Journal of Turkish Science Education, Vol : 3(1), 36-52.

Usman, Husaini. (2011). Manajemen. Teori, Praktik, dan Riset Pendidikan. Bumi Aksara. Jakarta.

Widiadnyana I W., Sadia I W. and Suastra I W. (2014). Pengaruh Model Discovery learning Terhadap Pemahaman Konsep IPA dan Sikap Ilmiah Siswa SMP Tahun Pembelajaran 2013/2014. E-journal program pascasarjana Universitas Pendidikan Ganesha Program Studi IPA. 4 (1): 1-13.

Yuliani, kiki and Saragih, Sahat. (2015). The Development Of Learning Devices Based Guided Discovery Model to Improve Understanding Concept and Critical Thinking Mathematically Ability of Students at Islamic Junior High School of Medan. Journal of Education and Practice; Vol. 6, pp 116-128.

Yupita, Ina Azariya, at el (2013). Penerapan model pembelajaran Discovery Learning untuk meningkatkan hasil belajar IPS di Sekolah Dasar. Accessed on 1 January 2019, from: http://ejournal. unesa .ac.id/index.php/jurnal-penelitian-pgsd/article/view/3017. 